DOI: 10.12731/2658-4034-2021-12-1-25-42

УДК 373 (31)

\title{
РАЗРАБОТКА ПРОГРАММЫ ВНЕУРОЧНОЙ ДЕЯТЕЛЬНОСТИ ПО ЭТНОКУЛЬТУРНОМУ ОБРАЗОВАНИЮ МЛАДШИХ ШКОЛЬНИКОВ СРЕДСТВАМИ ТРАДИЦИОННЫХ ЯПОНСКИХ ИСКУССТВ
}

\section{Митина Г.В., Шаламова О.О., Зорькина А.С.}

Цель. Одной из приоритетных задач начального общего образования на современном этапе определено духовно-нравственное развитие младиих школьников. В младшем школьном возрасте закладываются основы космополитического мировоззрения, воспитания поликультурной личности, способной к межкультурному взаимодействию. Предметом анализа в данной статье выступает поиск путей решения данной задачи. В качестве иели авторы обозначают определение методов и средств этнокультурного образования младших школьников.

Метод или методология проведения работы. Основу исследования составили методы изучения нормативных документов, анализа и обобщения психолого-педагогической литературы, изучения культурологической и этнологической литературы, моделирования образовательного прочесса.

Результаты. Результаты работы заключаются в том, что авторы раскрывают особенности младшего школьного возраста, создаюшие основу для этнокультурного образования и воспитания поликультурной личности: восприимчивость младших школьников $\kappa$ эмоционально-иенностному, духовно-нравственному развитию, гражданскому воспитанию. Одним из путей формирования основ космополитического мировоззрения, воспитания поликультурной личности является погружение школьников в культуру конкретного народа. Освоение традиций, обычаев, национальных искусств 
возможно проводить в рамках реализащии программы внеурочной деятельности «Традиционные искусства народов мира».

Область применения результатов. Результаты исследования могут быть применены при организации внеурочной деятельности в системе начального общего образования, подготовке педагогов для указанного уровня образования.

Ключевые слова: этнокультурное образование; программа внеурочной деятельности; младший школьник; культура Японии; традиционное искусство; фуросики.

\section{EXTRACURRICULAR ACTIVITIES PROGRAM DEVELOPMENT FOR ETHNOCULTURAL EDUCATION OF CHILDREN OF JUNIOR SCHOOL AGE BY MEANS OF JAPANESE TRADITIONAL ARTS AND CRAFTS}

\section{Mitina G.V., Shalamova O.O., Zor'kina A.S.}

Purpose. Spiritual and moral development of children of junior school age is considered to be one of the main goals of primary education. Younger students learn how to think globally, beyond the national boundaries, be tolerant, and communicate interculturally. The research is focused on determining how to complete this mission. The goal of the article is to identify means and methods of ethnocultural education of children of junior school age.

Methods. Methods primarily used in the research include analysis of normative documents, analysis and summary of psycho-pedagogical literature, literature on culturology and ethnology, and educational process modelling.

Results. In the paper, we determine the characteristics, which are vital for ethnocultural education and shaping a multicultural personality. The results show that one of the ways of developing a cosmopolitan outlook for junior school children is their immersion into the culture of a certain nation through their acquaintance with national customs and traditions, and arts. This can be done through extracurricular activities program entitled "World traditional arts". 
Practical applications. The findings are of direct practical relevance to organizing extracurricular activities for children of junior school age, and training primary teachers.

Keywords: ethnocultural education; extracurricular activities program; younger student; Japanese culture; traditional art; furoshiki.

\section{Введение}

В современном российском обществе нарастает актуальность проблемы развития этнокультурного образования. Граждане Российской Федерации являются жителями многонациональной, следовательно, поликультурной страны. Перед школой современное общество ставит новую задачу - воспитать культурную, творческую, самостоятельную личность, умеющую ориентироваться в постоянно изменяющемся мире. Данные задачи прописаны в Федеральном государственном образовательном стандарте начального общего образования (ФГОС НОО), который был разработан с учетом региональных, национальных и этнокультурных потребностей народов Российской Федерации.

ФГОС НОО декларирует обеспечение «сохранения и развития культурного разнообразия и языкового наследия многонационального народа Российской Федерации, права на изучение родного языка, возможности получения начального общего образования на родном языке, овладения духовными ценностями и культурой многонационального народа России». В качестве личностных результатов освоения основной образовательной программы начального общего образования в Стандарте указано: «формирование основ российской гражданской идентичности, чувства гордости за свою Родину, российский народ и историю России, осознание своей этнической и национальной принадлежности; формирование ценностей многонационального российского общества; становление гуманистических и демократических ценностных ориентаций»; «формирование уважительного отношения к иному мнению, истории и культуре других народов» [13].

На этапе начального общего образования целесообразно специально заниматься духовно-нравственным развитием ребенка, кото- 
рое предусматривает развитие жизненно важных качеств личности: патриотизма, уважения к людям, активной жизненной позиции, товарищества, толерантности. Именно толерантность определяет способность человека воспринимать не только образ жизни, мысли, поведение другого человека, но и уважать культуру и особенности жизни другой народности [7]. В младшем школьном возрасте закладываются основы космополитического мировоззрения, поликультурного образования личности, способной к межкультурному взаимодействию.

\section{Обзор литературы}

Исследование возможностей использования народного творчества в образовательной деятельности представлено в трудах Н.А. Бердяева, С.И. Гессена, П.Ф. Каптерева, В.С. Соловьева и др.

Идеи образования подрастающего поколения на основе традиций, обычаев, культуры конкретного народа заложены в трудах В.Ф. Афанасьева, Г.С. Виноградова, Г.Н. Волкова, М.Т. Картавцевой, И.С. Кона, В.С. Кукушина, В.А. Сухомлинского, К.Д. Ушинского и др.

Вопросы образования школьников средствами этнокультурных традиций, народного фольклора поднимались в работах В.Ф. Афанасьева, Э.Ф. Вертяковой, Г.В. Виноградова, Г.Н. Волкова, А.Ш. Гашимова, Н.Е. Еликбаева, Г.Е. Есима, А.Э. Измайлова, З.Г. Нигматова, К.Ш. Нурлановой, С.Е. Нурмуратова, В.И. Суханова, Я.И. Ханбикова.

Национальная культура как источник освоения ребенком ценностей своего народа рассматривалась в научных публикациях И. Алтынсарина, Ш.А. Амонашвили, Б.Т. Лихачева, М.И. Махмутова, Н.Д. Никандрова, М.Г. Тайчинова.

\section{Постановка задачи}

В педагогической науке и практике предлагается множество подходов к отбору содержания и организации этнокультурного образования младших школьников. Ограниченность представлений о географическом устройстве мира, недостаток опыта межкультурного общения младших школьников, с одной стороны, и возрастная 
потребность в познании мира, с другой, определяют возможность реализации задач этнокультурного образования младших школьников средствами традиционных искусств народов, территориально граничащих с Россией.

Методы исследования: изучение нормативных документов, анализ и обобщение психолого-педагогической литературы, изучение культурологической и этнологической литературы, моделирование образовательного процесса.

\section{Описание исследования}

В условиях интеграции России в мировое пространство сотрудничества и обмена научными, культурными и духовными ценностями увеличивается спрос на этнокультурную компетентность личности. А.Б. Афанасьева в своей статье «Этнокультурное образование: сущность, структура содержания, проблемы совершенствования» под этнокультурным образованием понимает «целостный процесс изучения, деятельностного освоения этнокультурного наследия и воспитания личности на этнокультурных традициях, процесс становления личности в осмыслении синхронных и диахронных информационных связей, учитывающих полиэтническую горизонталь географического пространства» [2, с. 79-82].

Младший школьный возраст является интенсивным периодом социализации, усвоения духовно-нравственных норм. Ребенок начинает активно общаться с одноклассниками, сверстниками. В этом общении важна настроенность на принятие феномена другого, рефлексивный характер взаимодействия. М.М. Бахтин по этому поводу пишет, что человеку «нужно почувствовать себя дома в мире других людей» [5]. Именно поэтому необходимо в этом возрасте приобщать ребенка к родному языку и культуре с одновременным формированием представлений о различных культурах мира.

Особое место в этнокультурном образовании младших школьников стоит уделить национальному искусству определенного народа. В национальном творчестве кроется богатая история народа, их менталитет, обычаи. Искусство каждого народа - это не просто 
развлечение и досуг, это отражение их миропонимания и самосознания. Народное творчество опирается на традиции и опыт [10, с. 44].

Знакомя детей с национальным творчеством народов мира важно не просто передать правильную технику воспроизводства какоголибо вида искусства, но и приобщать младших школьников к духовно-историческому опыту народа. В каждом народном промысле прослеживается глубинный смысл, традиционные нравы, зародившиеся много веков назад. Задача учителя начальных классов - донести культурное наследие этого народа через реализацию творческой деятельности. Национальное искусство способно не только рассказать о обычаях и традициях народа, но и показать, как живут люди, какую одежду они носят, какие продукты используют в пищу и др. Продукты национального искусства тесно связаны с человеком, его деятельностью и образом жизни. Они могут рассказать о достатке, вкусе, уровне образования [10, с. 44].

Несомненно, в процессе погружения в традиционные искусства различных народов мира, у ребенка происходит процесс формирования этнического самосознания. При этом, «личное» знакомство младших школьников с культурами разных народов будет иметь положительный результат в том случае, если соблюдать один из основных принципов культурологически ориентированного образования: от технологий типа «к ребенку - с культурой» к технологиям типа «с ребенком - к культуре» [4, с. 256].

О результативности этнокультурного образования можно судить по следующим критериям:

1. Когнитивно-познавательный. Данный критерий, главным образом, будет выражаться в определенной системе знаний о культуре разных народов.

2. Эмоционально-мотивационный. Проявление интереса к вопросам этнокультурного содержания. Желание узнать больше информации, расширить полученные знания не только в процессе образования, но и в самообразовании.

3. Аксиологический. Осознание важности и ценности культуры разных народов. 
4. Художественно-операциональный. Степень владения разными видами искусств различных культур.

5. Поведенческий. Владение нормами этики, толерантное отношение, соблюдение культуросообразного поведения.

6. Творческий. Опыт творческой деятельности в этнокультурной традиции [2, с. 189-195].

Для младших школьников, в силу возрастных особенностей, актуальными являются первые три критерия. В силу развитого возрастного познавательного интереса младший школьник проявляет интерес к культуре разных народов и может овладеть большим объемом информации этнокультурного характера. Зарождающиеся в шестилетнем возрасте моральная мотивация, самооценка и стремление к общению со сверстниками создают базу для осознания ценности культуры своего народа и разных народов [8]. Овладеть видами искусств и творческой деятельностью различных культур, демонстрировать культуросообразное поведение младший школьник в достаточной степени еще не готов в силу возрастной педантичности, преобладающей тенденция «отвечать ожиданиям других», индивидуальных художественно-творческих способностей [1].

Содержание этнокультурного образования многообразно, оно представляет большие варианты для реализации межпредметной связи дисциплин, изучаемых в начальной школе. Это дает возможность учителю показывать детям культуру различных стран незаметно, не мешая основной части образования, а лишь обогащая ее [14].

Безусловно, ведущей формой деятельности при организации этнокультурного образования служат занятия, осуществляемые непосредственно на уроке, но возможны также и другие формы, реализованные вне школы: экскурсии, прогулки, утренники, посещение выставок и музеев и др. Работу младших школьников можно организовать индивидуально, парно либо коллективно. Средствами обучения могут выступать различные предметы народностей, народные обычаи и традиции, изделия, музыка, книги и другое, относящееся к определенной культуре [6, с. 4987-4991]. 
Главным условием реализации этнокультурного образования является сохранение эмоционально-положительной атмосферы в классе. Необходимо сохранить доверительные отношения не только учителя с учениками, но и учеников между собой. Только создав положительную атмосферу в коллективе, можно сохранить и вызвать больший интерес учеников к изучению культур разных народов мира.

Ведущим фактором этнокультурного образования выступает возможность погружения школьника в реальную культуру конкретного народа. А здесь важна территориальная близость народов и возможность активного взаимодействия с представителями «другой культуры». Территория Дальнего Востока - самая восточная часть России, особенностью которой является территориальная близость с Китаем, Кореей и Японией. История, культура, искусство, образ жизни, мировосприятие народов этих стран привлекают к себе особое внимание. Есть представители китайского, японского, корейского языковых коллективов, которые проживают на территории Дальнего Востока, следовательно, школьники имеют возможность слышать аутентичную иноязычную речь и наблюдать особенности проявления иной культуры. Это является определяющим фактором в выборе объектов этнокультурного образования для подрастающего поколения.

Младший школьный возраст - это возраст любознательности. Ребенку нравится открывать неизведанное, познавать новое. Задача учителя - поддержать интерес ребенка и оказать поддержку в изучении необъятного для школьника мира.

Решать эту задачу можно в рамках внеурочной деятельности, которая, согласно ФГОС НОО, является неотъемлемой частью начального общего образования. Внеурочная деятельность организуется по разным направлениям развития личности, одном из которых является духовно-нравственное развитие. Данное направление решает задачи привития чувства патриотизма, любви к отечеству, к своей малой Родине, формирования гражданской ответственности, уважительного отношения к ценностям многонационального народа нашей страны, их культуре и истории, иному мнению. 
К реализации в начальной школе может быть предложена программа внеурочной деятельности «Традиционные искусства народов мира». Занятия проводятся один раз в неделю, следовательно программа учебного года рассчитана на 34 часа. Содержание программы представлено в таблице 1.

Таблииа 1.

Содержание программы внеурочной деятельности «Традиционные искусства народов мира» по классам

\begin{tabular}{|c|l|c|l|}
\hline Класс & Название раздела & Количество часов & Вид традиционного искусства \\
\hline 2 & Моя Россия & $\begin{array}{l}\text { Матрешка } \\
\text { хохлома } \\
\text { гжель } \\
\text { дымковская игрушка }\end{array}$ \\
\hline 3 & $\begin{array}{l}\text { Странабесная } \\
\text { восходящего } \\
\text { солнца (Япония) }\end{array}$ & 34 & $\begin{array}{l}\text { китайские фонарики } \\
\text { живопись }\end{array}$ \\
\hline 4 & $\begin{array}{l}\text { Страна утренней } \\
\text { свежести (Корея) }\end{array}$ & $\begin{array}{l}\text { икебана } \\
\text { оригами } \\
\text { каллиграфия } \\
\text { фуросики }\end{array}$ \\
\hline
\end{tabular}

В рамках данной статьи предлагается рассмотреть возможности этнокультурного образования младших школьников на основе изучения особенностей, традиций и искусства японского народа. Для этой цели разработана программа внеурочной деятельности для третьего класса: «Страна восходящего солнца». Тематическое планирование представлено в таблице 2 .

Япония - страна с интересной, богатой историей. Эта страна олицетворяет преданность своим традициям, удивляет суровостью, но в тоже время и красотой своего наследия. У жителей главным является созерцание и создание прекрасного, ни с чем не сравнимым, умение подчеркивать в каждой детали мирскую красоту. Япония долгое время была закрытой страной, это не могло не отразиться на культуре. Благодаря этому сформировалась самобытная японская культура. Говоря про культуру Японии необходимо 
помнить, что это островная страна. Это повлияло на обособленность искусства [11].

Таблица 2.

Содержание программы «Страна восходящего солнца»

\begin{tabular}{|c|c|c|c|}
\hline № & Раздел & $\begin{array}{l}\text { Количество } \\
\text { часов }\end{array}$ & $\begin{array}{c}\text { Содержание занятия, } \\
\text { форма проведения }\end{array}$ \\
\hline 1 & $\begin{array}{l}\text { Япония - страна } \\
\text { восходящего } \\
\text { солнца. } \\
\text { Почему? }\end{array}$ & 2 & $\begin{array}{l}\text { Рассказ учителя о стране с элементами } \\
\text { беседы, сообщения детей, работа с } \\
\text { картами, рассмотрение особенностей } \\
\text { географического положения страны. }\end{array}$ \\
\hline 2 & $\begin{array}{l}\text { Традиционные } \\
\text { искусства } \\
\text { японского } \\
\text { народа }\end{array}$ & 4 & $\begin{array}{l}\text { Рассказ учителя об истории } \\
\text { зарождения самобытной культуры } \\
\text { Японии, знакомство с традиционными } \\
\text { искусствами Японии (сообщения } \\
\text { детей), показ готовых работ } \\
\text { традиционного народного искусства. }\end{array}$ \\
\hline 3 & Оригами & 6 & $\begin{array}{l}\text { Знакомство с видами бумаги, ее } \\
\text { свойствами, изготовление изделия по } \\
\text { схеме, создание коллективной выставки } \\
\text { птичек, выполненных в технике } \\
\text { оригами. }\end{array}$ \\
\hline 4 & Икебана & 6 & \begin{tabular}{|l|} 
Создание осенней композиции из \\
листьев, шишек и ягод. Парная работа.
\end{tabular} \\
\hline 5 & $\begin{array}{l}\text { Фуросики: } \\
\text { Готовим } \\
\text { подарки к Дню } \\
\text { матери } \\
\text { Самый } \\
\text { волшебный } \\
\text { праздник в году } \\
\text { Что подарить } \\
\text { защитнику } \\
\text { Отечества? } \\
\text { Мой подарок } \\
\text { для мамы } \\
\text { Светлая Пасха }\end{array}$ & 8 & $\begin{array}{l}\text { Вводная беседа. } \\
\text { Изготовление подарка. Индивидуальная } \\
\text { работа. } \\
\text { Вводная беседа. } \\
\text { Подготовка новогодних украшений для } \\
\text { классного уголка. Парная работа. } \\
\text { Вводная беседа. } \\
\text { Изготовление подарка для папы. } \\
\text { Индивидуальная работа. } \\
\text { Вводная беседа. Подготовка подарка } \\
\text { маме. } \\
\text { Вводная беседа. Изготовление } \\
\text { корзинки под пасхальный кулич. }\end{array}$ \\
\hline 6 & Каллиграфия & 8 & $\begin{array}{l}\text { Знакомство с основами каллиграфии, } \\
\text { материалами и инструментами, } \\
\text { рассмотрение написания японских } \\
\text { иероглифов, самостоятельное } \\
\text { написание иероглифов по трафарету. }\end{array}$ \\
\hline & Итого & 34 & \\
\hline
\end{tabular}


Суровые условия жизни японского народа (землетрясения, цунами и др.) не могли не повлиять на формирование своеобразных японских традиций. Катаклизмы природы и умение любить мгновения натуральной красоты природы вдохновило японский народ оживлять неживую природу, придавать вещам и явлениям живые образы.

Также на формирование японской культуры большое воздействие имела религия. Она бала представлена в двух видах: буддизм и синтоизм. Буддизм в меньшей степени повлиял на культуру Японии, так как появился значительно позже синтоизма. Свой вклад эта ветвь религии внесла в архитектуру. Синтоизм представляет собой обожествление природных явлений. Это повлияло на то, что жители Японии относились к неодушевленной природе, как к живым созданиям [15].

Особое место в японской культуре занимает национальное творчество. Этим ремеслом в Японии занимаются на протяжении многих веков. Для японского народа в вещах ценились не только их практическое применение, но и красота, изящество и великолепие. Широкое распространение в мире получили японские направления прикладного искусства - оригами, нэцкэ, куклы - «нингё», изделия из керамики, тканная роспись и самая изысканная вещь - коробочка инро, которая предназначалась для хранения небольших по размеру предметов. Множество художественных изделий из керамики, которые также служат не только в качестве украшений, но и имеют практическую направленность, в их числе блюда, горшки, чайники и многое другое. Фарфоровые изделия также пользуются популярностью в Западных странах мира, в том числе вазы из тонкого фарфора [3].

На протяжении веков происходило множество изменений в японской культуре, но все же неизменным объектом восхищения оставалась природа. Японцы всегда стремились найти, одновременно, красоту и удобство, именно это определяло общую художественную направленность, оно влияло на самосознание человека, на его отношение к миру и окружающей действительности [15]. Так были сформированы традиционные искусства японского народа. Среди них: икебана, оригами, каллиграфия, фуросики. 
Решение задачи этнокультурного образования третьеклассников начинается с формирования представлений о культуре японского народа (когнитивно-познавательный критерий). Погружение в особенности культуры японского народа происходит не столько в форме представления информации учителем, сколько в форме индивидуальной и групповой самостоятельной работы младших школьников. Учитель готовит информацию об истории появления страны, ее политическом строе и условиях жизни населения. Подчеркивает в своих сообщениях, какую роль все эти факторы сыграли в становлении особенностей мировосприятия и поведения японского народа. Третьеклассникам, уже достаточно свободно в данном возрасте владеющим способами поиска информации, предлагается подготовить информацию о географическом положении страны, национальной одежде, письменности, национальном творчестве. Включение детей в самостоятельный сбор и представление информации создает условия для пробуждения и развития интереса к культуре другого народа (эмоционально-мотивационный критерий). Помня о том, что интерес как чувство является категорией неустойчивой, но в то же время составляет побудительную основу действия, важно, погружать младших школьников в культуру конкретного народа не столько информационно, сколько давая возможность практически приобщиться к этой культуре.

В своем исследовании мы остановились изготовлении с третьеклассниками традиционной упаковки повседневных предметов и продуктов - «фуросики». Это вид традиционного японского искусства представляет собой квадратный кусок различной по текстуре ткани, а также разной по размерам и расцветкам.

Буквально слово «фуросики» переводится как «банный коврик». Первоначально «фуросики» использовали при посещении бани. Посетители надевали специально предназначенную для посещения бани одежду, а свою повседневную одежду складывали в принесенный с собой кусок ткани. После посещения бани, люди переодевались в свою обычную одежду, а мокрую клали в эту ткань, поскольку таким образом было удобнее нести ее домой. Как правило, на ткани 
стоял семейный герб, что не позволяло перепутать чужой «фуросики» со своим.

В дальнейшем переноска вещей подобным способом стала набирать популярность. В нее начали заворачивать не только вещи, но и обычные предметы, которые брали с собой. Первыми, кто начал использовать фуросики для хранения предметов, стали торговцы, так они перевозили свои товары с одного места на другое. Японцы стали воспринимать фуросики как легкую, вместительную и удобную сумку.

Материал для ткани мог быть любым, но чаще предпочитали использовать именно хлопок или лен. Это объяснялось тем, что ткани из этих материалов получаются достаточно тонкими, что помогало легко их сворачивать, но в тоже время и прочными, что позволяло переносить большое количество предметов [16].

В последствии с помощью фуросики стали упаковывать подарки. Процесс дарения превратился в особый ритуал, обряд. Подарки выглядели уникально и элегантно. К тому же, данный способ упаковывания подарка символизировал об уважительном отношении дарителя. Фуросики всегда будет напоминать о том человеке, который преподнес такой подарок. Умение красиво и элегантно завернуть подарок, и украсить его, в Японии является целым искусством. Техника упаковывания подарков фуросики, несомненно, является творческой деятельностью. Данному способу упаковки подарков может научиться каждый. Есть много вариантов техники упаковывания, отличаться между собой они буду размером, цветом, материалом используемой ткани, а также дополнительным декором упаковки. Возможность и разновидность упаковывания зависит лишь от фантазии человека [15].

Данной техникой могут легко овладеть ученики младших классов. Упаковывания подарков в технике фуросики поможет развить у ребенка воображение, память, мелкую моторику, фантазию. Но главное то, что занимаясь во внеурочное время освоением техники упаковки подарков - «фуросики», младшие школьники осваивают культуру и ценности японского народа. Тем самым, дети незаметно для себя будут погружаться в мир Японии. 
Внеурочные занятия по изготовлению упаковки «фуросики» лучше проводить перед определенным праздником. Так как сама упаковка является универсальной, то ее можно применять на любой праздник и мероприятие. Занятия по упаковыванию подарка в технике фуросики будут интересны для детей старше 8 лет, когда мелкая моторика и пространственная ориентация уже достаточно сформированы. На занятия могут быть приглашены специалисты в области традиционных искусств из Японского Образовательного центра, Дома Дружбы, Генерального Консульства Японии в г. Хабаровске или студенты университета, изучающие японский язык и культуру. Соответствующая атмосфера создается за счет использования национального музыкального и «арома» фона.

Опишем одно из занятий с младшими школьниками по изготовлению упаковки в технике фуросики к Дню матери. После проведения вводной беседы с детьми на тему происхождения данного праздника, его важности, особенности проведения у японского народа, детей необходимо ознакомить с техникой, в которой они будут упаковывать. Для упаковывания подарка маме можно выбрать технику «фуросики» «четыре узла». Учитель демонстрирует готовое изделие, дети анализируют необходимые материалы, предполагают, как данная техника фуросики может называться и почему. Далее учитель с детьми поэтапно начинает работу в данной технике, контролируя и помогая при необходимости ученикам.

Благодаря данным внеучебным занятиям, посвященным упаковыванию подарков в технике фуросики, погружение младших школьников в культуру японского народа происходит постепенно на протяжении всего учебного года. Дети знакомятся с историей, культурой, искусством, традициями и обычаями японского народа, при этом, углубляя и расширяя знания про историю страны, в которой они живут. На этих занятиях посредством вовлечения в традиционные виды искусства, совместной работы и ценностного общения в процессе творческой деятельности школьников происходит Осознание важности и ценности культуры конкретного народа (аксиологический компонент). Младший школьник растет разносторонней 
«космополитичной» личностью, понимающей и принимающей общепризнанные правила и нормы поведения в мировом обществе.

\section{Список литературы}

1. Абрамова Г.С. Возрастная психология: Учеб. пособие для студ. вузов. 4-е изд., стереотип. М.: Издательский центр «Академия», 1999. 672 c. http://pedlib.ru/Books/3/0034/3_0034-2.shtml

2. Афанасьева А.Б. Этнокультурное образование: сущность, структура содержания, проблемы совершенствования // Знание. Понимание. Умение. 2009. № 3. С. 189-195. http://www.zpu-journal.ru/zpu/ contents/2009/3/Afanasieva/

3. Баженов В.М. Искусство Японии. М.: АСТ, 2021. 160 с.

4. Батищев Г.С. Особенности культуры глубинного общения // Вопросы философии. 1995. № 3. http://old.istu.ru/unit/epign/siip/psiped/3597/

5. Бахтин М.М. Эстетика словесного творчества. М., 1979. С. 98.

6. Гайсина Р.С., Головнева Е.В., Гребенникова Д.А. Этнокультурное образование младших школьников // Фундаментальные исследования. 2015. № 2-22. С. 4987-4991. https://www.fundamental-research. $\mathrm{ru} / \mathrm{ru} /$ article/view? $\mathrm{id}=38145$

7. Декларация принципов толерантности. Утверждена резолюцией 5.61 генеральной конференции ЮНЕСКО от 16 ноября 1995 года. http://www.tolerance.ru/toler-deklaraciya.php

8. Дубровина И.В. Психология. М., Академия, 1999. С. 343-436.

9. Жуковский И.В. Этнокультурное образование в многонациональном регионе // Педагогика. 2001. №3. С. 37-41.

10. Максяшин А.С. Декоративно-прикладное искусство: их сущность и содержание / А.С. Максяшин; И. Д. Уральская государственная юридическая академия. Екатеринбург, 2012. 44 с.

11. Пушакова А.Э. Япония. Введение в искусство и культуру. М.: Бомборо, 2019. $128 \mathrm{c}$.

12. Слободчиков В.И. Проблемы человека в современном мире // Педагогика. 2008. № 9. С. 33-39.

13. Федеральный государственный образовательный стандарт начального общего образования. https://gos.ru/ 
14. 亀川順代日本本語教師養成課程学生のパーソナリティ特性とそ の形成要因: 個人体験、自己評価、職業意識が及ぼす影響の検 討より在日台湾人子どもの読解力の測定、世界の日本語教育、 凡人社、2006年[第 16 号]、203 p.

15. 原田 日本語学校でもボランティアでもない新しい場所で教え る、アルク株式会社：2006年、75 p.

16. 野澤 素子 日本語で学ぶ日本: 講義シリーズ（日本語で学ぶ日 本）第 2 巻、教学出版KK、1999年、133 p.

\section{References}

1. Abramova G.S. Vozrastnaya psikhologiya [Developmental psychology]. M.: 'Academy' Publishing Center, 1999. 672 p. http://pedlib.ru/ Books/3/0034/3_0034-2.shtml

2. Afanaseva A.B. Znanie. Ponimanie. Umenie, 2009. no. 3, pp. 189-195. http://www.zpu-journal.ru/zpu/contents/2009/3/Afanasieva/

3. Bazhenov V.M. Iskusstvo Yaponii [Japanese art]. M.: AST, 2021. 160 p.

4. Batishchev G.S. Voprosy filosofii, 1995, no. 3. http://old.istu.ru/unit/ epign/siip/psiped/3597/

5. Bakhtin M.M. Estetika slovesnogo tvorchestva [Aesthetics of verbal creativity]. M., 1979, p. 98.

6. Gaysina R.S., Golovneva E.V., Grebennikova D.A. Fundamental'nye issledovaniya, 2015, no. 2-22, pp. 4987-4991. https://www.fundamentalresearch.ru/ru/article/view?id=38145

7. Declaration of principles of tolerance. Approved by Resolution 5.61 of the General Conference of UNESCO on November 16, 1995. http:// www.tolerance.ru/toler-deklaraciya.php

8. Dubrovina I.V. Psikhologiya [Psychology]. M., Akademiya, 1999, pp. 343-436.

9. Zhukovskiy I.V. Pedagogika, 2001, no. 3, pp. 37-41.

10. Maksyashin A.S. Dekorativno-prikladnoe iskusstvo: ikh sushchnost' $i$ soderzhanie [Decorative and applied art: their essence and content]. Ekaterinburg, 2012, 44 p.

11. Pushakova A.E. Yaponiya. Vvedenie v iskusstvo i kul'turu [Japan. An introduction to art and culture]. M.: Bomboro, 2019, 128 p. 
12. Slobodchikov V.I. Pedagogika, 2008, no. 9, pp. 33-39.

13. Federal state educational standard of primary general education. https:// fgos.ru/

14. 亀川 順代日本本語教師飬成課程学生のパーソナリティ特性とそ の形成要因: 個人体験、自己評価、職業意識が及ぼす影響の検 討より在日台湾人子どもの読解力の測定、世界の日本語教育、 凡人社、2006年[第 16 号]、203 p.

15. 原田 日本語学校でもボランティアでもない新しい場所で教え る、アルク株式会社: 2006年、75 p.

16. 野澤 素子 日本語で学ぶ日本: 講義シリーズ（日本語で学ぶ日 本）第 2 巻、教学出版KK、1999年、133 p.

\section{ДАННЫЕ ОБ АВТОРАХ}

Митина Галина Валентиновна, доцент кафедры теории и методики педагогического и дефектологического образования, кандидат педагогических наук, доцент

Тихоокеанский государственный университет

ул. Карла-Маркса, 68, г. Хабаровск, 680000, Российская Федерачия

gvmitina@mail.ru

Шаламова Ольга Олеговна, декан факультета востоковедения и истории, кандидат педагогических наук, доцент Тихоокеанский государственный университет ул. Карла-Маркса, 68, г. Хабаровск, 680000, Российская Федерачия pikapika@bk.ru

Зорькина Анна Сергеевна, студентка 4 курса направления 44.03.05 Педагогическое образование (с двумя профилями подготовки) Тихоокеанский государственный университет ул. Карла-Маркса, 68, г. Хабаровск, 680000, Российская Федерачия

2017103160@pnu.edu.ru 


\section{DATA ABOUT THE AUTHORS}

Mitina Galina V., Associate Professor of the Department of Theory and Methodology of Pedagogical and Defectological Education, Candidate of Pedagogical Science, docent

Pacific National University

68, Karl Marks St., Khabarovsk, 680000, Russia

gvmitina@mail.ru

ORCID: 0000-0001-7829-9856

Shalamova Ol'ga O., Dean, Faculty of Oriental Studies and History, Ph.D. of Pedagogical Sciences, Docent

Pacific National University

68, Karl Marks St., Khabarovsk, 680000, Russia

pikapika@bk.ru

Zor'kina Anna S., Fourth-year Student, Field of Study 'Pedagogical Education', 44.03.05 (Multi-specialty)

Pacific National University

68, Karl Marks St., Khabarovsk, 680000, Russia

2017103160@pnu.edu.ru 